\title{
PENGGUNAAN BAHASA INDONESIA DALAM INTERAKSI KELAS MATA PELAJARAN BAHASA INDONESIA (STUDI KASUS DI SMA NEGERI 2 SRAGEN)
}

\author{
Dina Handayani, Sarwiji Suwandi, Budhi Setiawan \\ Universitas Sebelas Maret
}

\begin{abstract}
Abstrak: Penelitian ini bertujuan untuk mendeskripsikan dan menjelaskan: (1) struktur percakapan dalam interaksi kelas antara guru dan siswa dan antarsiswa dan (2) fungsi bahasa guru dan siswa dalam interaksi kelas. Penelitian ini dilakukan di SMA Negeri 2 Sragen. Subjek penelitian ini adalah penggunaan bahasa guru dan siswa dalam pembelajaran bahasa Indonesia. Data yang berupa kalimat dan wacana dianalisis dengan teori Sinclair \& Coulthard (1975) dan teori Halliday (1973). Penelitian ini merupakan penelitian kualitatif dengan menggunakan metode studi kasus. Hasil penelitian ini adalah sebagai berikut. Pertama, pada struktur percakapan antara guru dan siswa tidak ditemukan tindak isyarat, sedangkan dalam struktur percakapan antarsiswa tidak ditemukan tindak pancingan, isyarat, pengakuan, dan metastatement. Namun, dalam kedua struktur percakapan tersebut ditemukan tindak baru, yaitu tindak pengulangan. Adapun urutan kedua struktur percakapan tersebut dari unit terbesar hingga unit terkecil, yaitu: pelajaran, transaksi, pertukaran, gerak, dan tindak. Kedua, fungsi bahasa yang terdapat dalam fungsi bahasa guru dan siswa, yaitu: fungsi instrumental, fungsi regulasi, fungsi interaksi, fungsi representasi, fungsi personal, dan fungsi heuristik.
\end{abstract}

Kata Kunci: analisis wacana, wacana kelas, wacana lisan, fungsi bahasa struktur percakapan

\section{USE OF INDONESIAN LANGUAGE IN INDONESIAN LANGUAGE CLASS INTERACTION (CASE STUDY IN SENIOR HIGH SCHOOL 2 SRAGEN)}

\begin{abstract}
This research aims to describe and explain: (1) the conversation structure in the classroom interaction of Indonesian language subject between teachers-students and among students and (2) the language function of the teachers' language and students' language in the classroom interaction. This research was conducted at SMA Negeri 2 Sragen. The subjects of this study were the use of language the teacher and students in Indonesian language course. The data in the form of sentences and discourse were analyzed by Sinclair \& Cotlthard (1975) theory and Halliday (1973) theory. This research belongs to qualitative research using case study methods. The results of this study are; first, in the teachers-students conversation structure and the studentsstudents conversation structure found new actions, namely, repeat. Both of the sequences of the conversation structure unit are from the largest to the smallest, namely: lesson, transaction, exchange, move, and act. Second, the language functions in the teachers' language and students' language, namely: the instrumental function, the regulatory function, the interaction function, the representational function, the personnel function, and the heuristic function.
\end{abstract}

Keywords: discourse analysis, classroom discourse, oral discourse, conversation structure, language function

\section{PENDAHULUAN}

Pendidikan merupakan salah satu aspek krusial bagi perkembangan dan kemajuan suatu bangsa. Sebab, pendidikan (Pujiono, 2014: 251) merupakan upaya yang mendasar untuk proses pengembangan sumber daya manusia agar lebih berkualitas. Di Indonesia, pendidikan formal memegang peranan penting dalam pengembangan sumber daya manusia. Pendidikan formal adalah pendidikan yang diselenggarakan oleh satuan pendidikan. Adapun proses belajar mengajar yang 
terjadi umumnya adalah di dalam kelas. Pembelajaran yang diselenggarakan oleh satuan pendidikan harus disesuaikan dan mentaati prinsip-prinsip kurikulum yang sedang berlaku.

Fadlillah (2014: 13-14) menjelaskan bahwa kurikulum merupakan sebuah wadah yang akan menentukan arah pendidikan. Kurikulum yang berlaku di Indonesia saat ini adalah Kurikulum 2013. Kurikulum 2013 adalah kurikulum yang menerapkan pendekatan ilmiah (scientific appoach). Menurut Majid (2014: 100) pendekatan tersebut meliputi kegiatan menanya, mencoba, mengolah, menyajikan, menyimpulkan, dan mencipta. Tidak seperti kurikulum terdahulu, kurikulum 2013 menuntut adanya penyelenggaraan pembelajaran yang lebih aktif.

Daryanto (2014: 16-19) mengungkapkan ada 14 prinsip penerapan Kurikulum 2013 dalam pembelajaran. Adapun prinsip-prinsip di antaranya, yaitu dari siswa diberi tahu menuju siswa mencari tahu dan dari guru sebagai satusatunya sumber belajar menjadi belajar berbasis aneka sumber. Dengan demikian, Kurikulum 2013 memungkinkan terjadinya interaksi antara guru dan siswa dan antarsiswa dalam mengonstruksi pengetahuan siswa. Sudiana (2005: 3) menyatakan bahwa dalam interaksi terjadi pertukaran pikiran, perasaan, atau ide secara kolaboratif (secara bersama-sama) di antara dua atau lebih yang menimbulkan saling pengaruh satu sama lainnya. Interaksi kelas merupakan interaksi yang berlangsung dalam konteks proses belajar mengajar dan pendidikan. Interaksi ini memiliki tujuan khusus, yaitu untuk mencapai tujuan pembelajaran. Adapun tujuan akhir dari pembelajaran bahasa adalah agar siswa memiliki keterampilan berbahasa, yaitu meliputi keterampilan menyimak, berbicara, membaca, dan menulis.

Interaksi kelas merupakan bentuk dari komunikasi edukatif dengan bahasa sebagai alatnya. Wulandari (2014: 82) menjelaskan bahwa bahasa merupakan media utama dalam mengekspresikan pikiran, mengonseptualisasikan dan menafsirkan dunia yang melingkupinya. Aziez (2015: 19) menyatakan bahwa bahasa pada prinsipnya digunakan oleh para pemakainya sebagai pembawa pesan yang ingin disampaikan kepada orang lain. Dari kedua pendapat tersebut dapat diketahui bahwa bahasa memegang peranan penting dalam interaksi kelas, sebab bahasalah yang menjembatani pengontruksian pengetahuan guru ke siswa dan siswa ke siswa.

Dalam kehidupannya, manusia merupakan makhluk yang aktif berkomunikasi. Hal ini dapat diketahui dari banyaknya ragam bahasa yang dihasilkan manusia. Suwandi (2008: 97) mengatakan bahwa variasi atau ragam tersebut dapat dilihat pada aspek bunyi (lafal), leksikal atau kata, struktur (bentukan kata dan bangun kalimat), dan juga gaya. Ia juga menambahkan bahwa keberagaman pemakaian bahasa itu bergantung pada tujuan pemakaian, pemeran serta (partisipan), latar (setting) pembicaraan, topik, dan fungsinya. Untuk mengungkap suatu maksud (yang sama), seorang anak akan menggunakan bahasa yang berbeda ketika dia bertemu dengan teman, guru, atau orang tuanya. Perbedaan itu juga akan terlihat, misalnya, ketika seorang anak (siswa) mengungkapkan hal yang sama di tempat yang berbeda (seperti di kelas atau di luar kelas).

Interaksi kelas merupakan suatu kegiatan timbal balik yang berdasar pada satu topik pembelajaran tertentu. Tahapan interaksi kelas sejak awal dibuka suatu pembelajaran hingga pembelajaran ditutup merupakan satu kesatuan yang terstruktur dan telah dirancang oleh guru. Satu kesatuan dalam kegiatan belajar mengajar inilah yang dinamakan wacana lisan. Windiatmoko (2016: 14) menyatakan bahwa secara garis besar wacana adalah satuan bahasa terlengkap daripada fonem, morfem, kata, klausa, kalimat dengan koherensi dan kohesi yang tinggi yang 
berkesinambungan, yang mampu mempunyai awal dan akhir yang nyata, disampaikan secara lisan atau tertulis, dapat berupa ucapan lisan dan dapat juga berupa tulisan, tetapi persyaratannya harus dalam satu rangkaian dan dibentuk oleh lebih dari sebuah kalimat.

Interaksi kelas membentuk struktur percakapan, baik antara guru dan siswa maupun antarsiswa. Dengan mengetahui struktur percakapan inilah guru dan siswa dapat saling memahami maksud dan tujuan komunikasi. Selain itu, dengan memahami struktur percakapan, maka dapat dipahami pula fungsi bahasa yang diujarkan oleh guru dan siswa pada saat interaksi kelas berlangsung sehingga yang menjadi tujuan pembelajaran dapat dicapai dengan mudah.

Sebelumnya, Lestari (2006) telah melakukan penelitian analisis wacana lisan pada interaksi belajar mengajar di kelas 5 SDIT Nurhidayah Surakarta dengan menitik beratkan penelitiannya pada aspek struktur wacana, fungsi bahasa, dan fungsi partikel. Peneliti lainnya, Untoro (2010) juga telah melakukan penelitian serupa, yaitu melakukan penelitian analisis wacana lisan interaksi guru dan siswa di kelas yang merupakan studi kasus pemakaian bahasa di SMA Negeri 3 Sragen dalam mata pelajaran bahasa indonesia, biologi, dan sosiologi dengan menitikberatkan penelitian pada aspek struktur wacana lisan, fungsi bahasa, partikel wacana lisan, serta alih kode dan campur kode dalam interaksi belajar mengajar. Penelitianpenelitian tersebut merupakan penelitian yang dilakukan pada saat Kurikulum Tingkat Satuan Pendidikan (KTSP) masih diberlakukan.

Berdasarkan uraian di atas, maka dilakukan penelitian yang berfokus pada struktur percakapan dan fungsi bahasa yang terdapat dalam interkasi kelas. Penelitian ini menggunakan metode penelitian studi kasus. Adapun yang menjadi objek penelitian ini adalah interaksi kelas mata pelajaran bahasa Indonesia di SMA Negeri 2 Sragen.

\section{HASIL DAN PEMBAHASAN}

\section{Struktur Percakapan Dalam Interaksi Kelas}

Teori Sinclair \& Coultahrd (1975) merupakan teori pertama yang berbicara tentang interaksi kelas dan merupakan teori terlengkap yang mengungkap struktur wacana lisan dalam interaksi kelas. Tidak hanya untuk meneliti struktur percakapan antara guru dan siswa, teori ini juga digunakan peneliti untuk meneliti struktur percakapan antarsiswa dalam interaksi kelas.

\section{Pelajaran (Lesson)}

Pelajaran yang terdapat dalam struktur percakapan antara guru dan siswa dan antarsiswa adalah pelajaran bahasa Indonesia dengan topik presentasi karya tulis ilmiah (KTI) yang diselenggarakan dengan teknik tanya jawab (diskusi).

\section{Transaksi (Transaction)}

Baik dalam struktur percakapan antara guru dan siswa maupun antarsiswa hanya terdapat satu struktur transaksi, sebab terdapat pertukaran-pertukaran dalam struktur percakapan antara guru dan siswa dan antarsiswa yang tergabung dalam sebuah transaksi. Adapun transaksi dalam struktur percakapan ini, meliputi transaksi penginformasian, transaksi pengarahan, dan transaksi pancingan.

\section{Pertukaran (Exchange)}

Baik struktur percakapan antara guru dan siswa maupun antarsiswa terdiri dari dua pertukaran, yaitu pertukaran batas dan pertukaran bebas. Pertukaran bebas dalam struktur percakapan antara guru dan siswa terdiri dari informasi guru, perintah guru, pancingan guru, dan pemeriksaan. Pertukaran dalam struktur percakapan antarsiswa terdiri dari pancingan siswa, informasi siswa, dan pemeriksaan.

\section{Gerak (Move)}

Gerak yang terdapat dalam struktur percakapan antara guru dan siswa dan antarsiswa, yaitu gerak susun, gerak pusat, 
gerak pembukaan, gerak penjawaban, dan gerak lanjutan.

\section{Tindak (Act)}

\section{Penanda (marker)}

Tindak Penanda berfungsi untuk menandai batas-batas dalam wacana.

G : (28) Mau saya ambil acak?

(29) Tinggal dua kelompok.

(30) ( $\mathrm{G}$ berhenti bicara) (31)

Oke. (32) Kelompoknya

Luky, silakan.

Kata 'oke' pada tindak (31) merupakan pembatas antara tawaran dari $\mathrm{G}$ untuk kelompok yang ingin maju presentasi dan keputusan dari $G$ atas kelompok yang harus maju presentasi.

S2 : (79) Bagaimana, Mbak Eriza? Sudah puas?

S8 : (80) (mengangguk)

S2 : (81) Baik. (82) Pertanyaan dari Mas Aldi akan dijawab oleh penyaji kelima, yaitu Mas Aji.

Kata 'baik' pada tindak (81) merupakan pembatas antara reaksi S8 atas pemeriksaan yang dilakukan oleh S2 mengenai kepuasan jawaban yang diberikan oleh kelompok dan penyerahan pertanyaan dari S9 oleh S2 untuk dijawab S7.

\section{Pembukaan (starter)}

Tindak pembuka berfungsi untuk memberikan informasi tentang atau mengarahkan perhatian atau pemikiran terhadap suatu area untuk membuat respon yang benar terhadap inisiasi lebih memungkinkan.

G : (1) Assalamualaikum wr. wb.

SS : (2) Wa'alaikumsalam wr. wb.

G : (3) Huda sudah masuk?

Tindak (3) merupakan pertanyaan dari $G$ untuk mengarahkan perhatian seluruh siswa pada kehadiran S1 di kelas.

$$
\begin{gathered}
\text { S2 : (45) Apakah } \\
\text { pertanyaan? (46) Di sini } \\
\text { kami membuka dua sesi, } \\
\text { satu sesi tiga pertanyaan. }
\end{gathered}
$$

Tindak (45) merupakan pertanyaan yang diujarkan oleh S2 untuk memberikan informasi kepada SS bahwa sesi tanya jawab telah dibuka.

\section{Pancingan (elicitation)}

Tindak pancingan berfungsi untuk meminta respon linguistik.

G : (285) Kalau kira-kira yang tadi itu $t u$ dia ditentukan oleh lingkungannya, dia bisa berdampak tidak?

SS : (286) Bisa.

Tindak (285) merupakan pertanyaan yang diberikan oleh $\mathrm{G}$ untuk mendapatkan jawaban linguistik dari SS mengenai bisa atau tidaknya manusia dibentuk dan ditentukan oleh lingkungan.

\section{Pemeriksaan (check)}

Tindak pemeriksaan berfungsi untuk memungkinkan guru memastikan apakah ada masalah yang menghambat keberhasilan pembelajaran.

$\mathrm{G}$ : (7) Kemarin kan tidak masuk. (8) Bisa mengikuti ya nanti ya?

Tindak (8) merupakan tindak yang diujarkan oleh $\mathrm{G}$ untuk memeriksa apakah S1 dapat mengikuti kegiatan pembelajaran yang akan dilaksanakan karena pada pertemuan sebelumnya ia tidak masuk sekolah.

$$
\begin{aligned}
& \text { S2 : (79) Bagaimana, Mbak } \\
& \text { Eriza? Sudah puas? }
\end{aligned}
$$

Tindak (79) merupakan tindak pemeriksaan yang diujarkan S2 untuk memeriksa apakah S8 telah merasa puas atas jawaban yang diberikan oleh kelompok.

\section{Direktif (directive)}

Tindak direktif berfungsi untuk meminta tanggapan nonlinguistik.

$$
\begin{aligned}
\mathrm{G}: & (31) \quad \text { Oke. } \\
& \text { Kelompoknya }
\end{aligned}
$$


silakan. (33) Ya, kursinya dibawa ke depan. (34) Nanti presentasi seperti biasanya ya!

Tindak (32) merupakan perintah dari G kepada kelompok S4 untuk melakukan presentasi KTI di depan kelas. Tindak (33) merupakan perintah dari G kepada kelompok S4 untuk membawa kursi mereka ke depan kelas. Tindak (34) merupakan perintah dari $G$ kepada kelompok S4 untuk melakukan presentasi seperti biasanya.

S10 : (140) Hei, diam. Hei, diam. (141) (SS diam)

Tindak (140) merupakan bentuk perintah dari S10 kepada SS agar tidak bersuara.

\section{Informatif (informative)}

Tindak informatif berfungsi untuk memberikan informasi.

G : (369) Oke. (370) Kita udah selesai.

Tindak (370) merupakan pernyataan dari $G$ yang isinya berupa informasi yang menyatakan pembelajarn pada pertemuan tersebut telah selesai.

S2 : (174) Ya, kami tampung terlebih dahulu.

Tindak (174) merupakan informasi dari S2 yang menyatakan bahwa komentar yang sudah masuk akan ditampung terlebih dahulu.

\section{Dorongan (prompt)}

Tindak dorongan berfungsi untuk memperkuat sebuah arahan dengan meanyarankan bahwa guru tidak lagi meminta tanggapan, namun mengharapkan atau menuntut terus-menerus.

$\mathrm{G}$ : (76) Silakan kalau mau menanggapi.

Kata 'silakan' pada tindak (76) merupakan bentuk dorongan yang diberikan oleh G kepada SS untuk turut memberikan tanggapan mengenai presentasi KTI yang telah dilaksanakan.
S2 : (162) Di sini kami buka sesi kedua. (163) Silakan yang mau bertanya.

Kata 'silakan' pada tindak (163) merupakan bentuk dorongan yang diberikan oleh S2 kepada SS sebagai untuk turut berpartisipasi dalam kegiatan tanya jawab sesi kedua.

\section{Petunjuk (clue)}

Tindak petunjuk berfungsi memberikan informasi tambahan yang membantu siswa untuk menjawab pancingan atau mematuhi arahan.

G : (247) Jadi kalian sebagai peneliti, sebagai peneliti itu juga bisa menguatkan apa yang kalian tulis, apa yang kalian presentasikan.

Tindak (247) merupakan ujaran yang berisi petunjuk dari $G$ untuk membantu kelompok yang presentasi menjawab pertanyaan yang sebelumnya disampaikan oleh S10, yaitu dengan memberikan penguatan pada tulisan dan presentasi KTI.

S2 : (46) Di sini kami membuka dua sesi, satu sesi tiga pertanyaan.

Tindak (46) merupakan petunjuk yang diujarkan oleh S2 kepada SS berisi informasi bahwa sesi tanya jawab akan dibuka sebanyak dua sesi dengan kesempatan yang diberikan hanya untuk tiga penanya per sesi.

\section{Tawaran (bid)}

Tindak tawaran berfungsi untuk memberi isyarat keinginan untuk berkontriabusi pada wacana.

$\mathrm{G}$ : (165) Yang belum pernah bertanya, yo, silakan bertanya. (166) Ini tinggal dua kelompok, satu sudah maju, tinggal satu. Nanti selesai KTI-nya. (167) Ayo, silakan! (168) (S11 mengangkat tangan) 
Tindak (168) berupa perilaku mengangkat tangan oleh S11 merupakan bentuk isyarat bahwa S11 ingin berkontribusi dalam wacana kelas setelah sebelumnya mendapat dorongan dari $\mathrm{G}$.

$$
\begin{aligned}
\text { S2 : } & \text { (45) Apakah } \\
& \text { pertanyaan? (46) Di sini } \\
& \text { kami membuka dua sesi, } \\
& \text { satu sesi tiga pertanyaan. } \\
& \text { (47) (S8 dan S9 mengangkat } \\
& \text { tangan). }
\end{aligned}
$$

Tindak (47) merupakan penawaran diri dari S8 dan S9.

\section{Nominasi (nomination)}

Tindak nominasi berfungsi untuk memanggil atau memberikan izin kepada siswa untuk berkontribusi pada wacana.

G : (403) Dinda. Ya, Dinda.

Tindak (403) merupakan pemberian izin dari G kepada S10 untuk terlibat dalam wacana kelas, yaitu S10 menyampaikan pertanyaan untuk $G$ pada tindak (404).

S2 : (48) Ya, Mbak Eriza.

Tindak (48) merupakan pemberian izin dari S2 kepada S8 untuk terlibat dalam wacana kelas.

\section{Pengakuan (acknowledge)}

Tindak pengakuan berfungsi hanya untuk menunjukkan bahwa inisiasi telah dipahami, dan jika awalan itu direktif maka bermaksud agar siswa melakukan sesuatu.

$$
\begin{aligned}
\text { G : } & \text { (345) ... Nah, saya minta } \\
& \text { tolong karena dulu di kelas } \\
& \text { satu kita sudah pernah } \\
& \text { praktik berdebat. Ya kan? } \\
& \text { Sudah pernah kita lombakan } \\
& \text { juga, sudah pernah ada yang } \\
& \text { mendapatkan juara juga, } \\
& \text { dipilih oleh teman-teman } \\
& \text { kalian sendiri. Ya? Nanti } \\
& \text { saya ikutkan pesertanya dulu } \\
& \text { yang di kelas satu... } \\
\text { SS : } & \text { (346) Dinda, Josse. } \\
\text { G : } & \text { (347) Dinda, Josse, sama } \\
& \text { siapa? Ada dua tok? }
\end{aligned}
$$

$$
\begin{aligned}
\mathrm{SS} & : \text { (348) Dua. } \\
\mathrm{G} & : \text { (349) Dua ya? } \\
\mathrm{S} 66 & :(350) \text { Tiga. } \\
\mathrm{G}: & \text { (351) Iya, satu kelompok } \\
& \text { gitulo. Kan tiga kan? } \\
\mathrm{S} 6: & \text { (352) Ya. } \\
\mathrm{G}: & \text { (353) Dinda, Josse, sama } \\
& \text { siapa lagi? } \\
\mathrm{S} 6: & : \text { (354) Aji. } \\
\mathrm{G}: & \text { (355) Sama Aji. (356) Ya. } \\
\text { Kata } & \text { 'ya' pada tindak (356) }
\end{aligned}
$$
merupakan pengakuan dari G bahwa S10, S6, dan S7 adalah siswa-siswa yang pernah mengikuti lomba debat saat di kelas X. Dengan memerhatikan inisiasi direktif pada tindak (345), dapat diketahui bahwa maksud dari tindak tersebut adalah $\mathrm{G}$ menginginkan ketiga siswa tersebut untuk kembali mengikuti lomba debat mewakili sekolah.

\section{Jawaban (replay)}

Tindak jawaban berfungsi untuk memberikan respon linguistik yang sesuai dengan pancingan.

G : (285) Kalau kira-kira yang tadi itu tu dia ditentukan oleh lingkungannya, dia bisa berdampak tidak?

SS : (286) Bisa.

Tindak (286) merupakan pernyataan dari SS sebagai jawaban atas pertanyaan $\mathrm{G}$ pada tindak (285).

S6 : (71) Jadi, menurut saya, menurut saya pribadi, lebih baik itu untuk mengembangkan, mengembangkan hobi. E, dilihat dari data kami tadi, di hasil penelitian itu banyak sekali ada manfaat dan ada kekurangan....

Tindak (71) merupakan pernyataan argumentasi dari S6 sebagai jawaban yang ia berikan atas pertanyaan S8 pada tindak (50).

\section{Reaksi (react) \\ Tindak reaksi berfungsi untuk memberikan respon nonlinguistik sesuai}


yang didefinisikan oleh direktif sebelumnya.

G : (144) Oke. Gini ya. (145) Ssstttt. (mengangkat tangan) (146) (para siswa diam)

Perilaku diam yang ditunjukkan oleh para siswa pada tindak (146) merupakan bentuk respon nonlinguistik akibat adanya tindak (145) yang dilakukan oleh G sebagai tanda ia meminta para siswa untuk tidak berbicara.

S10 : (140) Hei, diam! Hei, diam! (141) (SS diam)

Perilaku diam yang diperlihatkan SS pada tindak (141) merupakan bentuk respon nonlinguistik sebagai akibat adanya perintah dari S10 pada tindak (140)

\section{Komentar (comment)}

Tindak komentar berfungsi untuk memberikan contoh, mengembangkan, membenarkan, memberikan informasi tambahan.

$\mathrm{G}$ : (283) Ya, ini PR untuk kalian. Jadi, namanya penulis kalau kalian menuliskan sesuatu itu tidak asal menulis. Ya nanti kalian cek lagi, cari bukunya lagi. Ya kan? Teorinya sampai mana sehingga nanti bisa dikaitkan dengan hasil kalian. Ya? Oke, seperti itu.

Tindak (283) merupakan pernyataan yang diujarkan oleh $\mathrm{G}$ kepada kelompok yang presentasi sebagai informasi tambahan agar kelompok melakukan perbaikan pada KTI-nya.

S10 : (121) Tadi kan tekniknya nggak ada observasi. Kenapa di data dan sumber data peristiwa? Padahal peristiwa itu kan dapatnya dari kita observasi.

Tindak (121) merupakan pertanyaan yang diujarkan oleh S10 kepada kelompok yang presentasi untuk membenarkan teknik yang digunakan dalam penelitian.

Penerimaan (accept)
Tindak penerimaan berfungsi untuk menunjukkan bahwa guru telah mendengar atau melihat dan bahwa informasi, jawaban, atau reaksi adalah benar.

G : (399) Nanti silakan datang.

SS : (400) Ya.

Kata 'ya' pada tindak (400) merupakan tanda bahwa para siswa telah mendengar dan menerima perintah dari $\mathrm{G}$ pada tindak (399).

S2 : (159) Bagaimana, Mbak Dinda? Sudah puas?

S10 : (160) Ya.

Kaya 'ya' pada tindak (160) merupakan tanda bahwa S10 telah menerima jawaban-jawaban yang diberikan oleh kelompok yang presentasi atas pertanyaan-pertanyaan sanggahan yang ia ajukan.

\section{Penilaian (evaluate)}

Tindak penilaian direalisasikan dengan kesesuaian dan menandai pertanyaan termasuk kata-kata dan frasa, seperti 'bagus', 'menarik', 'poin tim', mengomentari kualitas jawaban, bereaksi atau inisiasi, juga dengan 'ya', 'tidak', 'bagus', 'baik', dengan intonasi tinggi dan pengulangan jawaban siswa baik semua.

G : (331) Karena fokusnya
hanya pada satu kelas
sebenernya lumayan mampu
kita menyimpulkan, tapi
sayangnya kalian kurang
aktif.
'kurang aktif' yang diujarkan oleh $\mathrm{G}$ pada tindak (331) merupakan bentuk penilaian dari $\mathrm{G}$ atas berjalannya diskusi kelas dalam presentasi KTI.

S3 : (134) ... Jadi, fokusnya ke game online bukan game yang lainnya.

S10 : (135) Lha kan game itu kan juga bisa e, anu, menganu karakter kan juga bisa.

SS : (136) Ya. Ya, betul.

S10 : (137) Nggak cuma game online aja yang, dan fokusnya terlalu pada laki- 
laki, padahal kan perempuan kan juga pasti pernah bermain game.

SS : (138) Betul. Betul.

Kata 'betul' pada tindak (136) dan (138) merupakan penilaian dari SS terhadap komentar yang diberikan oleh S10 terkait game dan informan yang dipilih dalam penelitian. Dalam hal ini SS menyetujui pernyataan yang diujarkan oleh S10 pada tindak (134), (135), dan (137).

\section{Pemakaian jeda (silent stress)}

Tindak pemakaian jeda berfungsi untuk menyorot penanda ketika berfungsi sebagai awalan pertukaran batas yang menunjukkan batas transaksi.

G : (28) Mau saya ambil acak?

(29) Tinggal dua kelompok.

(30) ( $\mathrm{G}$ berhenti bicara) (31)

Oke. (32) Kelompoknya Luky, silakan.

Tindak (30) merupakan tindak pemakaian jeda yang menyorot penanda, yaitu kata 'oke' yang menunjukkan batas transaksi 5 dan 6.

S6 : (240) Oke. Oke. (241) (berdiri, hening sebentar) (242) E, e, Sebenarnya gini ya. E, di kita, e, kita kan menjelaskan, e, ya, oke. E, Tadi kan bagian kepuasan diri. Pada intinya...

Jeda (hening sebentar) pada tindak (241) merupakan batas transaksi yang menyorot kata 'oke' pada tindak (240).

\section{Metastatement}

Tindak metastatement berfungsi untuk membantu siswa untuk melihat struktur pelajaran, untuk membantu mereka mamahami tujuan dan maksud pertukaran selanjutnya.

$\mathrm{G}$ : (382) Penugasan kalian masih ada resensi materi yang lain. Resensinya tidak hanya dari novel, dari buku, tetapi juga bisa dari gambar, dari lagu. Dari? (hening sebentar) Bisa meresensi lagu.

Tindak (382) merupakan informasi dari $G$ yang berisi penugasan yang diujarkan oleh $\mathrm{G}$ kepada para siswa untuk membantu mereka melihat struktur pelajaran selanjutnya setelah membuat resensi dari pementasan teater.

\section{Kesimpulan (conclusion)}

Tindak kesimpulan berfungsi untuk membantu siswa memahami struktur pelajaran, tetapi kali ini dengan meringkas apa yang menjadi bagian dari wacana sebelumnya.

G : (154) Jadi intinya seperti ini ya, Mbak Dinda. Dari kelompok tersebut, dia memang sengaja membagikan angket kepada pemain game online. Makanya tidak memilih asal-asal cewek-cowok dipilih seenaknya mereka sendiri. Gitu ya, Mbak Dinda. Nanti dikasih penjelasan.

Tindak (154) merupakan pernyataan anaforis berupa kesimpulan yang ditarik oleh $G$ atas jawaban yang diberikan oleh S5 pada tindak (152) untuk menjawab pertanyaan dari $\mathrm{S} 10$.

S2 : (297) Baik. (298) Kesimpulan akhirnya adalah baik dampak positif maupun negatif yang didapat dari dokumen dan hasil analisis data tentang cara untuk menanggulangi dampak negatif game online itu tergantung dari bagaimana siswa atau pengguna membatasi dirinya dari pengaruh game online serta keseriusannya dalam menanggulangi dampaknya.

Tindak (298) merupakan kesimpulan akhir hasil presentasi KTI yang diujarkan oleh S2. 
Putaran (loop)

Tindak putaran berfungsi adalah untuk mengembalikan wacana ke tingkat sebelum siswa berbicara.

S12 : (205) Pertanyaannya kurang lengkap. (SS tertawa)

S6 : (206) E, kalau misal kurang lengkap, bisa tolong diulangi lagi?

Tindak (206) merupakan putaran yang berfungsi supaya S12 mengulangi pertanyaannya karena S6 tidak menangkap isi pertanyaan tersebut secara utuh. Pada tindak tersebut intonasi naik terjadi mulai dari pengujaran kata 'tolong'.

\section{Bisikan (aside)}

Tindak bisikan adalah contoh sebenarnya dari guru yang berbicara kepada dirinya sendiri.

G : (335) Jadi ingat debat bahasa Indonesia.

Tindak (335) merupakan ujaran dari $G$ yang tidak benar-benar ditunjukkan kepada para siswa. Tindak ini diujarkan G kepada dirinya sendiri.

S1 : (96) Saya mau, mau gimana ya? (97) E, saya kurang jelas gitu lo.

Tindak (96) merupakan pertanyaan dari S1 yang ditujukan kepada dirinya sendiri mengenai bagaimana ia akan menyampaikan tanggapannya kepada kelompok yang presentasi di depan kelas.

\section{Pengulangan (repeat)}

Selain 22 tindak yang disebutkan Sinclair \& Coulthard (1975), dalam struktur percakapan antara guru dan siswa dan antarsiswa ditemukan tindak pengulangan yang berfungsi sebagai bentuk penekanan terhadap pokok ujaran. Pengulangan ini bisa berupa pengulangan terhadap ujaran dalam pembuka atau ujaran yang berupa pengulangan jawaban siswa.

S9 : (385) Ngumpulinnya kapan, $\mathrm{Bu}$ ?

$$
\begin{array}{rlr}
\text { G } & :(386) \quad \text { Ya. } & \text { (387) } \\
& \text { Mengumpulkannya kapan, } \\
& \text { Bu? }
\end{array}
$$

Tindak (387) merupakan tindak pengulangan pertanyaan dari S9 yang diujarkan $G$ sebelum ia menjawab pertanyaan tersebut.

S12 : (178) Ya. Sebelumnya tadi kan Mas Jose bilang kalau lebih baik mengembangkan hobi daripada bermain game. (179) Nah, bermain game sendiri kan itu kan sudah hobi ya.

Tindak (178) merupakan tindak pengulangan pernyataan dari S6 yang diujarkan kembali oleh S12 sebelum ia menyampaikan komentarnya terkait pernyataan tersebut.

Ramirez (Rani, Arifin \& Martutik, 2006: 62-66) telah mengungkapkan bahwa dalam gerak penjawaban (answering) dan pelanjutan (follow-up) terdapat tindak pengulangan (repeat). Namun, ia tidak menjelaskan fungsi dari tindak tersebut. Dalam penelitian ini, tindak pengulangan (repeat) yang ditemukan pada struktur percakapan antara guru dan siswa dan antarsiswa berfungsi untuk sebagai penekanan. Dari lokasi ditemukannya tindak penguatan (repeat), yaitu bergabung menjadi satu dengan tindak jawaban (replay) dan tindak komentar (comment) dapat diketahui bahwa tindak penguatan (repeat) dalam interaksi kelas ini digunakan untuk memberikan penekanan jawaban (replay) dan komentar (comment).

Dari 22 tindak dalam struktur percakapan yang dianalisis dalam penelitian ini, Untoro (2010) dan Lestari (2006) hanya mampu menemukan 21 tindak. Adapun tindak yang tidak mereka temukan, yaitu tindak pemakaian jeda (silent stress). Bila Untoro (2010) hanya mendeskripsikan struktur wacana lisan interaksi guru dan siswa di kelas pada unit tindak, Lestari (2006) mampu mendeskripksikan struktur wacana lisan dalam interaksi kelas dari unit tindak 
hingga pelajaran. Dalam penelitian ini berhasil dideskripsikan struktur percakapan dalam interaksi kelas dari unit tindak hingga pelajaran yang mencakup 2 struktur percakapan, yaitu antara guru dan siswa dan antarsiswa.

\section{Fungsi Bahasa Dalam Interaksi Kelas}

Fungsi bahasa Halliday (1973) merupakan fungsi bahasa yang strukturnya diperoleh dari bahasa anak yang dianggap sebagai asal fungsional yang paling jelas dari sistem bahasa. Teori ini digunakan peneliti untuk meneliti fungsi bahasa guru dan siswa dalam interaksi kelas.

\section{Fungsi instrumental}

Fungsi instrumental, yaitu bahasa menghasilkan akibat tertentu karena berupa ungkapan perintah (imperatif).

G : (144) Oke. Gini ya. (145) Ssstttt. (mengangkat tangan) (146) (kelas hening)

Partikel 'sssstt' pada tindak (145) merupakan bentuk perintah dari G kepada SS agar tidak mengeluarkan suara (diam).

S10 : (140) Hei, diam. Hei, diam. (141) (SS diam)

Tindak (140) merupakan bentuk perintah dari S10 kepada SS agar tidak bersuara (diam).

\section{Fungsi Regulasi}

Fungsi regulasi, yaitu bahasa digunakan untuk mengendalikan tingkah laku orang lain.

G : (247) Jadi kalian sebagai peneliti, sebagai peneliti itu juga bisa menguatkan apa yang kalian tulis, apa yang kalian presentasikan.

Tindak (247) merupakan nasihat yang dari $G$ untuk mengendalikan cara kerja siswa sebagai peneliti.

S2 : (45) Apakah ada pertanyaan? (46) Di sini kami membuka dua sesi, satu sesi tiga pertanyaan.

Tindak (46) merupakan petunjuk yang dimaksudkan untuk mengatur peristiwa tanya jawab yang akan berlangsung.

\section{Fungsi Interaksi}

Fungsi interaksi, yaitu bahasa digunakan untuk mempertahankan keberlangsungan komunikasi demi terjalinnya interaksi sosial.

\section{G : (3) Huda sudah masuk?}

Tindak (3) merupakan pertanyaan kehadiran $\mathrm{S} 1$ yang diujarkan oleh $\mathrm{G}$ untuk mempererat hubungan sosial dalam interaksi kelas, sebab sebelumnya S1 tidak masuk karena kecelakaan.

S2 : (36) Assalamualaikum wr. wb.

Tindak (36) merupakan salam yang digunakan S2 sebagai pembuka presentasi KTI.

\section{Fungsi Representasi}

Fungsi representasi, yaitu bahasa digunakan untuk menyampaikan informasi baru (bukan imajinatif): untuk mengomunikasikan konten yang (dianggap oleh pembicara sebagai) tidak diketahui oleh penerima.

G : (331) Karena fokusnya hanya pada satu kelas sebenernya lumayan mampu kita menyimpulkan, tapi sayangnya kalian kurang aktif.

Pada tindak (331) bahasa digunakan $G$ untuk membuat pernyataan penilain terhadap presentasi yang telah dilaksanakan.

S1 : (235) Bentar, saya mau menambahkan. (236) Nah, menurut saya antara kepuasan diri sama teori yang disampaikan oleh kelompoknya Mbak Gabby itu ada korelasinya....

Pada tindak (236) bahasa digunakan untuk menjelaskan korelasi antara kepuasan diri dan teori yang digunakan dalam penelitian.

\section{Fungsi personal}

Fungsi personal, yaitu bahasa dapat digunakan untuk menunjukkan kepribadian atau perasaan seseorang. 
G : (271) Sebenarnya saya juga bingungnya di sini karena kamu kan menyebutnya hasil negatif sama positif. Tapi kalau pembahasan yang kamu tulis di sini lo ya, di KTI, kan tidak semua bisa dimasukkan (menunjuk layar proyektor), itu kok banyak dampak negatifnya sebenarnya. Kira-kira gimana kalian untuk mengalihkan teorinya tersebut?

Pada tindak (271) bahasa digunakan untuk mengungkapkan perasaan $G$, yaitu perasaan bingung $G$ terhadap teeori yang digunakan dalam penelitian.

S1 : (96) Saya mau, mau gimana ya?

(97) E, saya kurang jelas gitu lo.

(98) Kalau misalkan....

Pada tindak (97) bahasa digunakan untuk menyatakan perasaan, yaitu perasaan kurang jelas (bingung).

\section{Fungsi Heuristik}

Fungsi heuristik, yaitu bahasa digunakan untuk memperoleh informasi dan pengetahuan melalui penggunaan bentuk-bentuk pertanyaan.

$\mathrm{G}$ : (20) Terus ini ada yang nggak masuk?

Pada tindak (20) bahasa digunakan oleh

$\mathrm{G}$ untuk memperoleh informasi ketidakhadiran siswa di kelas.

S8 : (50) Menurut kalian sendiri, e, lebih penting mengembangkan hobi kalian atau bermain game online?

Pada tindak (50) bahasa digunakan untuk mengetahui tingkat kepentingan antara mengembangkan hobi dan bermain game online.

Dari 7 fungsi bahasa yang dianalisis dalam penelitian ini, Untoro (2010) berhasil menemukan 6 fungsi bahasa guru dalam interaksi kelas. Hal tersebut sama dengan hasil temuan fungsi bahasa dalam penelitian ini. Namun, dalam penelitian ini menghasilkan temuan baru, yaitu berupa temuan fungsi bahasa siswa dalam interaksi kelas. Baik dalam penelitian
Untoro (2010) maupun penelitian ini tidak ditemukan fungsi imajinasi, sebab topik pelajaran pada saat data penelitian diambil tidak berkaitan dengan karya sastra.

\section{SIMPULAN}

Wacana lisan dalam interaksi kelas mata pelajaran bahasa Indonesia kelas XI IPA 3 SMA Negeri 2 Sragen membentuk struktur percakapan antara guru dan siswa dan antarsiswa. Dalam struktur percakapan antara guru dan siswa tidak ditemukan tindak isyarat (cue), sedangkan dalam struktur percakapan antarsiswa tidak ditemukan tindak pancingan (elicitation), isyarat (cue), pengakuan (acknowledge), dan metastatement. Namun, dalam kedua struktur percakapan tersebut ditemukan tindak baru, yaitu tindak pengulangan (repeat). Adapun urutan kedua struktur percakapan tersebut dari unit terbesar ke unit terkecil, yaitu: (1) pelajaran, yakni unit tertinggi dalam wacana kelas yang mengandung suatu topik tertentu; (2) transaksi, yakni penanda batas antarpertukaran; (3) pertukaran, yakni unit di bawah transaksi yang mengandung subtopik dalam pelajaran; (4) gerak, yakni bentuk klasifikasi tindak pada struktur percakapan dalam interaksi kelas; dan (5) tindak, yakni unit terkecil pada struktur interaksi kelas yang mengandung fungsi tertentu dari bahasa guru atau siswa.

Bahasa yang digunakan oleh guru dan siswa dalam interaksi kelas mata pelajaran bahasa Indonesia kelas XI IPA 3 SMA Negeri 2 Sragen memiliki fungsi yang sama, yaitu: (1) fungsi instrumental, yakni ujaran yang berisi perintah agar seseorang melakukan suatu perbuatan; (2) fungsi regulasi, yakni ujaran untuk mengendalikan tingkah laku seseorang; (3) fungsi interaksi, yakni ujaran untuk mempertahankan komunikasi dan interaksi sosial; (4) fungsi representasi, yakni ujaran untuk menyampaikan informasi baru yang belum diketahui oleh lawan bicara; (5) fungsi personal, yakni ujaran untuk menunjukkan kepribadian atau perasaan seseorang; dan (6) fungsi heuristik, yakni 
ujaran yang berupa kalimat tanya untuk memperoleh informasi atau pengetahuan. Adapun fungsi yang tidak ditemukan

\section{REFERENSI}

Aziez, F. 2015. Pengajaran Bahasa Komunikatif: Teori dan Praktik. Yogyakarta: Pustaka Pelajar.

Daryanto. 2014. Pendekatan Pembelajaran Saintifik Kurikulum 2013. Yogyakarta: Penerbit Gava Media.

Fadlillah. 2014. Implementasi Kurikulum 2013 dalam Pembelajaran SD/MI, SMP/MTs, \& SMA/SMK. Yogyakarta: Ar-Ruzz Media.

Halliday, M. A. K. 1973. Explorations of Language Study. London: Edward Arnold.

Lestari, S. 2006. Analisis Wacana Lisan pada Interaksi Belajar Mengajar di Kelas 5 SDIT Nur Hidayah Surakarta. Skripsi Tidak Dipublikasikan. Universitas Sebelas Maret, Surakarta.

Majid, A. (2014). Implementasi Kurikulum 2013. Bandung: Interes Media.

Pujiono, S. 2014. Kesiapan Guru Bahasa Indonesia SMP dalam Implementasi Kurikulum 2013. Litera, 13(2), 250263.

Rani, A., Arifin, B. \& Martutuik. 2006. Analisis Wacana: Sebuah Kajian Bahasa dalam Pemakaian. Malang: Bayumedia Publishing.

Sinclair, J. McH. \& Coulthard, R. M. 1975. Towards an Analysis of Discourse. London: Oxford University Press.

Sudiana, I N. (2005). Interaksi Belajar Mengajar. Bali: Alfina Primatama.

Suwandi. 2008. Serbalinguistik (Mengupas Pelbagai Praktik Berbahasa). Surakarta: LPP UNS dan UNS Press.

Untoro, R. D. 2010. Analisis Wacana Lisan Interaksi Guru dan Siswa di Kelas (Studi Kasus Pemakaian Bahasa di SMA Negeri 3 Sragen dalam Mata Pelajaran Bahasa adalah fungsi imajinasi, sebab topik pelajaran yang diangkat tidak berkaitan dengan karya sastra.

Indonesia, Biologi, dan Sosiologi). Tesis Tidak Dipublikasikan. Universitas Sebelas Maret, Surakarta.

Windiatmoko, D. U. 2016. Analisis Wacana dalam Gurindam XII dan Nilai Pendidikan Karakter serta Implikasinya sebagai Materi Ajar Sastra. Kembara, 1(3), 12-22.

Wulandari, Y. 2014. Tajuk Rencana Harian Kompas dan Media Indonesia Mengupas Nasib TKI: Analisis Perbandingan Stuktur Teks. Bahastra, XXXII(1), 81-108. 